This is a self-archived version of an original article. This version may differ from the original in pagination and typographic details.

Author(s): Giulianotti, Richard; Itkonen, Hannu; Nevala, Arto; Salmikangas, Anna-Katriina

Title: Sport and civil society in the Nordic region

Year: 2019

Version: Accepted version (Final draft)

Copyright: (c) 2017 Taylor \& Francis

Rights: In Copyright

Rights url: http://rightsstatements.org/page/InC/1.0/?language=en

Please cite the original version:

Giulianotti, R., Itkonen, H., Nevala, A., \& Salmikangas, A.-K. (2019). Sport and civil society in the Nordic region. Sport in Society, 22(4), 540-554.

https://doi.org/10.1080/17430437.2017.1390906 


\title{
Sport and Civil Society in the Nordic Region
}

\section{Richard Giulianotti (Loughborough University, and University College of Southeast Norway) \\ Hannu Itkonen (University of Jyväskylä, Finland) \\ Arto Nevala (University of Eastern Finland) \\ Anna-Katriina Salmikangas ((University of Jyväskylä, Finland)}

\begin{abstract}
This paper examines the key elements within the relationships of sport and civil society in the Nordic region. The analysis combines a focus on broad themes and developments in Nordic sport and civil society, such as the role of the welfare state and the impacts of neoliberalism, with consideration of specific national experiences, notably the case of Finland. The discussion has four main parts. First, we set out the principal features of the 'Nordic model' of society, and how it shapes sport and civil society relations. Second, we advance a Finnish case-study of Nordic sport and civil society, examining the historical connections of three sectors - civil, public and private to the national sport culture. Third, we briefly consider how, in recent decades, the Nordic model has encountered and sought to respond to neoliberalism and globalization processes. Finally, we explore how Nordic societies have sought to influence globalization processes and 'global civil society' through sport, specifically through taking lead roles within the transnational 'sport for development and peace’ sector.
\end{abstract}

Keywords: Nordic region; sport, civil society; welfare state; globalization 


\section{Introduction}

The Nordic region - comprising the northern European states of Denmark, Finland, Iceland, Norway and Sweden - is widely regarded as having a special model of social, political and economic relations, which is reflected in the particular interconnections of sport and civil society. As we explain, the Nordic model has specific social characteristics centred on a strong welfare state, many civil society organizations, and close and effective partnerships across state, civil society and market. In sport, this model is associated with substantial government investment, 'sport for all' policies, and thriving national networks of sport clubs and associations. Yet, the model does have some significant variations in its development across different Nordic nations, and it has also come under pressure from recent globalization processes and the rise of neoliberal social policies.

In this paper, we explore the key elements of these relationships between sport and civil society in the Nordic region. Our approach is to examine these relationships on one hand with respect to core themes and developments (such as the welfare state and recent impacts of neoliberalism), and on the other hand with regard to specific case-study national locations and substantive areas (for example, in the ‘sport for development and peace' area). In terms of our national case-studies, we draw significantly but not exclusively on the case of Finland, a country that otherwise is under-represented in discussions of the Nordic region compared to the Scandinavian countries of Denmark, Norway, and Sweden. Finnish case-studies allow us to explore concisely and in relatively greater depth some of the particular issues that arise in the sportcivil society symbiosis, though we do recognize that significant variations and differences are to be found in the experiences of other Nordic nations.

Our discussion is thus organized into four main parts. In part one, we outline the principal features of the Nordic model and how it shapes sport and civil society relations. In part two, we advance a Finnish case-study of Nordic sport and civil society, examining the historical 
connections of three sectors - civil, public and private - to the national sport culture. In part three, we briefly consider the issue of how, in recent decades, the Nordic model has encountered and sought to respond to neoliberalism and globalization processes. In part four, we explore how Nordic societies have sought to influence globalization processes and 'global civil society' through sport, specifically through taking vanguard roles within the transnational 'sport for development and peace' sector.

\section{Part 1: The Nordic Model: Welfare State, Society and Sport}

The modern 'Nordic model’ of politics, economy and civil society has been a long-running subject of analysis and debate in political, public and academic spheres. Andersen et al. (2007) argue that, while there are notable differences between Nordic countries, they do share a common model that is marked by a 'comprehensive welfare system... financed by taxes'; high spending on 'human capital', including childcare, education, research and development; and, a strong political role for trade unions with clear wage coordination and 'relatively generous' unemployment benefits (2007: 13-14). Similarly, Alestalo et al. (2008) observe that the model is defined by stateness, particularly high welfare state provisions; universalism, in social rights to welfare; and equality, such as in protecting the political, social and economic status of the working classes, women, the disabled and the old. To this, we might add that the Nordic countries are exceptionally strong in social mobility. A recent international study showed that Scandinavia had the lowest influence of parental educational background on the child's educational progression. When measured numerically, the influence level was 1.4 in Finland, about 2 in Norway and Sweden, and about 6.3 in England (Marginsson 2015).

Nordic societies stand in contrast to alternative social models that dominate other nations and regions. Esping-Andersen (1989) famously differentiated between three such models of welfare capitalism: the social democratic model of the Nordic countries; the liberal model, which 
includes a focus on means-tested welfare support, as in the United States; and, the conservative or corporatist model, based largely on social insurance contributions, exemplified by countries like Austria and France. These models of welfare capitalism reflect three deeper approaches to statemarket-civil society relations. The Anglo-American model has tended to view the state as a threat to the private interests and liberties of citizens within the civil sphere. Conversely, Swedish and other Nordic models consider the relationship to be more interdependent, as the universalism of the state balances and supports individual and community interests within civil society (Trägårdh 2007). Thus, Nordic states have provided substantial funding and other support for civil society organizations, whereas in the American model these bodies are expected to be essentially selfreliant (Eliasoph 2013: 64-5).

Despite their many common features, individual Nordic countries have undergone distinctive historical developments and societal changes. For example, modern Finland embarked on a relatively late path towards its own particular variant of building the welfare state, mainly due to class-based civil war in 1918, and a subsequent process of determined national unification. The conflict established long-lasting political and cultural divisions, so that Finnish sport and other civic organisations were divided into two camps: bourgeois and working class. These divisions were challenged from the 1920s onwards, by renewing land ownership and implementing compulsory education, fighting wars against the Soviet Union in 1939-1944, and in the post-war reconstruction and the strengthening of the welfare state through the 1950s and 1960s (Kettunen 2006). Moreover, in contrast to other Nordic nations, Finland favoured its farming sector in ways that delayed rapid industrialization until the 1960s; hence, the Finnish welfare state emerged relatively late but grew rapidly in tandem with the migration of rural populations into towns (Kettunen 2006; Antikainen \& Rinne 2012). The Finnish state had an essential role in developing the market economy and in tackling economic and societal differences. The idea of 'social citizenship', tied closely to the welfare state, was actively favoured by Finnish government officials, including in the right to sport 
and exercise, before an exceptionally deep recession in the early 1990s led to the cutting and privatization of public services in the spirit of neoliberalism. As we explain later, such restructuring came to fundamentally alter sport policies and practices in Finland (Antikainen \& Rinne 2012; Ball 2012).

Notwithstanding these distinctive features, we may begin by confirming that a specific Nordic model of sport and civil society is a legitimate object of analysis. In their subtle analysis of sport policy across Scandinavian nations, Bergsgard and Norberg (2010) argue that a distinctive regional model does exist. They state that this model is characterized by "large, national and voluntary sports organizations with a near monopoly on competitive sports on the one hand and a significant involvement in sports from the government on the other” (2010: 567).

The strong social qualities of the Nordic sporting model are revealed in several ways. First, some Nordic societies have enshrined sport as an important social good to the extent that it is viewed as a human right. The 1998 Sport Act in Finland, for example, understood sport to be a force for diverse social benefits, such as health and welfare, the development of young people, environmental sustainability, cultural diversity and social equality (Kidd and Donnelly 2000).

Second, Nordic societies have been at the global forefront of mass sport or sport for all movements. For example, Green and Collins (2008) found that Finland has followed on a 'path dependency' that prioritizes 'sport for all' policies since the early 1960s, with substantial legislative backing and government spending on public sport facilities and other infrastructure. Reflecting a welfare society ethos, the sport-for-all approach contrasts markedly with nations such as Australia, where a free-market political philosophy is more embedded, and where the state is likely to put greater emphasis on elite sport development.

Third, women have long played significant roles in Nordic sport and civil societies. The role of women in the Nordic countries has historically deviated from many other European countries, for example in regard to political rights as well as in education or employment (Jalava 
2012). In the early twentieth century, women in the Nordic countries developed their own physical activity cultures especially in gymnastics. Moreover, as gender equality developed, so special attention was paid to equality issues in physical activity and sport, for example in Finland with respect to sport legislation and decision-making (Itkonen 1999: 59-60). Since 1995, a special prize, called “piikkarit” has been awarded in Finland for significant work in promoting gender equality and diversity in physical activity and sport.

A fourth point to be made here, on which we elaborate later, is that the civil sphere has at times challenged the growing influence of commercial interests and neoliberal cultures within Nordic sport. In elite level football, for example, Norwegian supporter organizations and movements successfully opposed the attempts by some commercial television stations to change match kick-off times. Strong debates also ensued from some supporters on whether their football club (Vålerenga of Oslo) should include match-day 'entertainment' activities in order to attract wider fans and sponsors (Hognestad 2015).

While the broad Nordic policy model prioritises social democracy and inclusion, in reality the position of sport, politics and society is inevitably more complicated and challenging. Thus, for example, while Nordic societies evidence higher levels of social equality than many other regions, significant social tensions and divisions remain along the lines of class, gender, ethnicity, and urban/rural relations which can be seen in the objectives of the Finnish Act on the promotion of sports and physical activity (390/2015). ${ }^{1}$ These tensions and divisions are invariably reflected within sport. For example, there are strong correlations between levels and types of sport participation and different social classes. While there is a sharp general decline in organised sport participation after adolescence, the middle-classes are more likely to benefit through higher levels of physical activity in adult life (Skille 2011). In regard to gender, despite major advances, many scholars in Nordic societies have highlighted the continuing challenges that women face in

\footnotetext{
${ }^{1}$ Ministry of Culture and Education, Finland (2015).
} 
achieving equality in sport in regard to their participation, recognition and political influence

(Pfister \& Sisjord 2013). Certainly, there are spectacular examples of ethnic minority athletes such as Henrik Larsson and Zlatan Ibrahimovic in Swedish football gaining national and global acclaim. Yet, the Nordic region does show evidence of institutionalized and everyday racism in sport (cf. Scott 2015), while further challenges arise in the sporting engagement and integration of recent incoming migrants, particularly refugees to Sweden, Norway and Denmark. Thus, overall, the Nordic model for sport, civil society and other social spheres has some way to go before realizing its full social democratic ideal.

\section{Part 2: The Complex Histories of Nordic Sport and Civil Society: The Case of Finland}

The development of modern Finnish sport provides us with important insights into the distinctive historical relationships between Nordic sport and civil societies. The first modern Finnish civil organisations date to the late 17th century, when Finland was under Swedish rule. Faced with a state that was structurally weak and unable to solve social problems, Finns established their own organisations such as temperance, religious and popular educational associations, and youth and worker movements (Alapuro \& Stenius 1989: 20-39; Itkonen 2002: 13-14). In the $19^{\text {th }}$ century, the records indicate that 341 societies were founded, mainly by the gentry, and most of these associations involved some sports: for example, shooting (at 35 societies), skiing (15), skating (18), men’s gymnastics (60), women’s gymnastics (23), and cycling (26) (Nygren 1989: 35). In 1856, the first sport club in Finland was established - the Björneborgs Segelförenign (Pori Sailing Club) by merchants, industrialists and leading members of the local bourgeoisie, with the purpose of securing use of the coastal area (Laine 1984: 1). ${ }^{2}$

It is possible to describe the subsequent modern development of Finnish sport clubs by utilizing the ideal-type analytical approach of Max Weber. The different historical periods of

\footnotetext{
${ }^{2}$ Pori is a small municipality on the west coast of Finland.
} 
these sport clubs may be identified as follows: 1 ) The age of organizational culture, dating from the early 1900s to the 1930s; 2) The age of hobby-competition culture from the 1930s to the 1960s; 3) The age of intense competition from the 1960s to the 1980s; 4) The age of divergent activities, from the 1980s onwards, featuring the expansion and fragmentation of physical training and sport (Itkonen 2002: 36; 2011; 2015: 49-56).

The first age, of organizational culture, saw the 1905 general strike marking an expansion of worker mobilisation in politics and civil society. In the same year, there were 526 youth associations with around 40,000 members, with a similar number of members to be found in temperance societies (Alapuro \& Stenius 1989: 38-40; Siisiäinen 1991: 2). After Finnish independence from the Soviet Union in 1917, a short but bloody civil war erupted in 1918. After the war, two types of civil organization emerged - either bourgeois or working class - and these tended to build their own meeting halls, particularly for clubs that were tied to the civil guards, or youth and workers' associations (Vasara 1997: 44-45). Class-based organizational cultures were replicated in sport and physical activity through the bourgeois Finnish Gymnastics and Sports Federation, founded in 1906, and its counterpart, the Finnish Workers' Sports Federation, which was formed in 1919 (Laine 1984: 558-559; Hentilä 1982: 92, 163).

Many Finnish sport clubs emerged within other civil society organizations, such as the fire brigade, workers’ associations or youth associations. Hence, a variety of activities on offer included popular enlightenment and 'common good' education, such as around temperance, fire safety, youth activities, language classes and political education. Thus, the general instrumental value of sport was recognized (Hentilä 1982: 92, 163; Alapuro \& Stenius 1989: 43). Meanwhile, the public administration of sport developed soon after Finland gained independence in 1917. In 1920, the national sports board was founded under the Ministry of Education. In the 1930s, the town, city and county municipalities started to organise governance by founding their own sport boards (Ilmanen 2015; Itkonen \& Salmikangas 2015: 548.) 
The second age, of hobby-competition in sport (1930s to 1960s), saw the increased importance of competitive sports, including athletics, gymnastics, skiing, wrestling, and Finnish baseball (Itkonen 2002: 39-40). After years of war, the 1950s also witnessed a rapid expansion of public sport facilities across the nation, as urban municipal authorities built swimming pools, ice skating rinks, and fitness and gymnastics halls, while rural municipalities established playing fields (Ilmanen 1995). The delivery of these sport facilities by the Finnish state system provided the longterm infrastructure and built environment that were essential for national sport organizations and cultures to flourish within civil society.

During the third age, of intense competition in sport (running from the 1960s to the 1980s), more attention was directed to the effectiveness of the organisation of sports training, which entailed the sectorization and professionalization of coaching (Itkonen 1996: 224). The 1960s were also the decade in which physical fitness activities expanded rapidly, despite the fact that these activities were not highly regarded by sport clubs (Ilmanen 1995: 283-285). Thus, for some time, competitive sport retained its dominant position in club activities.

The fourth age, of divergent activities (from the 1980s onwards), has witnessed the expansion of sport in terms of organisation and content. The traditional sports movement changed: old track-and-field and ski clubs were overtaken by team sports clubs, internationally-based power and skill sports clubs (karate, judo and other martial arts), and new associations independent of central sport federations. The trend has also been towards greater specialisation in sport clubs and in sports practice (Siisiäinen 1991: 3).

Since the 1980s, changes in the wider civil sphere have significantly altered how sport and physical activities are organised and oriented. Sport clubs in general now fall into two main groups: sport- and performance-oriented clubs, and clubs oriented towards wider socio-cultural interests and activities. The first group of clubs tend to participate in competitions, have higher sporting goals which lead to an intensification of training, or be involved at elite level and include 
media and marketing wings. These clubs aim for success, good results and records. The second group, featuring socio-cultural clubs, are not involved in competitions, and have a broader orientation. They aim to satisfy their members' need for physical activity, or to search for experiences through physical training, or to develop group activities. They use physical training to achieve defined objectives, such as health promotion, rather than competitive goals (Itkonen 2002: 46).

Turning more fully to the issue of the welfare society, the 1960s onwards were evidently an important period for sport and society, as Finland experienced substantial economic growth and national prosperity, enabling significant and effective legislation to be implemented, to the benefit of Finnish society. For example, the Primary Health Care Act (1972) and the Act of Children’s Day Care (1973) showed the important role of legislation in building the national welfare system (Itkonen \& Salmikangas 2015: 548).

Sport policy was part of this process and included substantial socio-political planning. For example, Finland’s ‘sport for all’ policy was considered to be especially important for the wider society due to greater urbanisation and the emergence of less physically active working practices, which necessitated an increase in physical activity in leisure time (Itkonen 2000: 21). In response, the Commission on Physical Fitness (1966-70) sought to promote 'sport for all', with support from the widespread construction of indoor facilities by municipalities which was financed by the Ministry of Education (Kokkonen 2015: 178-179; Kuntoliikunnan suunnittelu 1970: 60)

In the 1970s and 1980s, the Finnish state played a strong guiding role in delivering municipal sport, primarily through the standardisation of facilities that was supported by public delivery, funding and counselling (Kokkonen 2015: 17). In 1980, after several years of parliamentary discussions on sport, the New Sport Act came into force. The Act established sport boards in every municipality, and strengthened sport services by increasing the number of sport officials, supporting more voluntary sport club activities, and building functional sports facilities 
(Ilmanen 2015: 32). This Act confirmed the distribution of work, which is still in existence, between public and civil spheres in sport. According to this Nordic model, the public sports administration system should create equal conditions for all citizens, while sports organizations are responsible for practical arrangements across sport activities. As we explain later, like other Nordic nations, Finnish sport and society came under pressure to 'liberalize' during the 1990s, yet the public sector has retained a strong role in the delivery of sport.

Overall, to summarise, Finnish sport has been a component of the wider development and differentiation of civil society, and is embedded within the making of a national version of the Nordic welfare state. The strong public sector emerged from the building of a national welfare system, while the resources of towns and municipalities in delivering sport and physical activities have been and continue to be very important. The 'sport for all' ethos, backed by the building of public sport facilities, reflects the Nordic emphasis on universalism, stateness, and equality. In accordance with this Nordic model, municipal sport services are understood to be an important part of welfare services and of the wider investment in 'human capital', in terms of enhancing the health and functional capacity of citizens.

\section{Part 3: The Demise of the Nordic Model? Neoliberalism, Sport and Civil Society}

In recent times, there has been considerable speculation on the extent to which the Nordic model is fragmenting and losing ground to neoliberal and other global policy influences, with the potential for direct impacts on the relationships between sport and civil society. ${ }^{3}$ Markers of potential change include the transnational spread of neoliberal ideas and policies amidst the global economic downturn; the argument that state spending on universal welfare benefits is unsustainable and harmful for a healthy economy; the entry of the private sector into public domains such as health, education and sport; reductions in corporation taxes, and the reluctance of states to save failing

\footnotetext{
${ }^{3}$ On the neoliberal economic model, see Harvey (2005).
} 
businesses such as Saab in Sweden; mass immigration, including those caught up in the refugee crises, into the Nordic countries; and, the ejection of governments by conservative and right-wing parties, and the attendant rise of populist and far-right movements, focusing particularly on migration issues.

It is important to look carefully at these claims of change, and to keep them in perspective. Nordic countries continue to have relatively high levels of GDP spending on state services, and to offer strong support to civil society organizations including in sport. ${ }^{4}$ In sport, the Nordic region is a long way from the neoliberal idyll, where down-sized states stop investing in public sport facilities and organizations, and turn to the market and to community voluntarism to fill the gaps. Therefore, we do not subscribe to the view of the business magazine The Economist, that the hold of neoliberalism in the Nordic region is such that the doyen of free-market economics, Milton Friedman, 'would be more at home in Stockholm than in Washington, DC' (The Economist, 2 February 2013).

That said, neoliberalism has had impacts in Nordic society and sport. Wollebæk and Selle (2008: 47-8) claim that, even in oil-rich Norway, 'social democracy has lost its hegemony’. Part of this switch is registered in civil society, in the strong growth of 'expressive' organizations in the fields of 'culture, leisure and advocacy', which are 'individualist and consensus-oriented' rather than social democratic in their structures. In elite-level sport, there are clear political tensions between, on one side, the prominent Nordic norms of citizenship, social welfare, voluntarism and democracy, and on the other, the powerful norms of consumerism, commercialism, professionalism, and neoliberalism. For example, in Sweden, clubs in elite-level and other sports have long been subject to the rule promoting social inclusion and democracy that requires their $51 \%$ ownership by a non-profit club rather than by private companies or entrepreneurs. This regulation has been contested in sports like football and ice-hockey by commercial forces that favour a free-market

\footnotetext{
${ }^{4}$ Perhaps the strongest illustration of social democratic policies is provided by the Norwegian national sovereign wealth fund, derived from state-controlled oil and gas profits, which was valued at around US\$900 billion in late 2016 and which is still firmly under state control.
} 
ownership model, but it has also been strongly defended by spectator groups on the grounds of participatory democracy (Carlsson \& Backman 2015; Junghagen 2016; cf. Fahlen 2006). In Denmark there has been a notable growth in the number of clubs that have moved towards commercial ownership models. More substantially, in football and ice-hockey, all Nordic countries are increasingly integrated into the neoliberal economic systems of elite global sport, as instanced by worldwide labour markets for the top players, sponsorships by leading national and international corporations, and substantial revenues from sale of television rights.

The case of Finland provides some deeper insights into the wider impacts of neoliberalism in Nordic sport and society. Finland was directly affected by the 1990s global recession, leading to the realignment of state-civil society relations and, in neoliberalist vein, to the growth of the private sector for sport and physical activities alongside the decline of the public sector. At that time, hardly any Finnish politician was defending the welfare state. The political right, as well as the Social Democrats, began to criticise the "closed" and inefficient old welfare state. Thus, the welfare state lost its traditional political backing (Ahlqvist \& Moisio 2014). In turn, the private 'sport industry' has expanded rapidly, generating billions of Euros in business (Laine 2015: 77). For example, the usage of private sport facilities and services increased nearly fivefold over the years 2000-2010, while adult spending in this area rose by over $74 \%$ in one single year (Laine 2015: 82-83). For affluent social groups, physical activity has become a sphere of popular leisure, a source of well-being, and a key focus for consumption, through a mix of commercial fitness clubs, private sports facilities and personal trainers. Market strategies and management methods have taken root in sport and wider civil society. Civic activities have become more business-like, while the cost of involvement in sport clubs has increased. The public sector continues to own over $70 \%$ of sport facilities, but investment and expenditure on sport undergoes closer scrutiny and is less generous than in the past. In most municipalities, as part of the drive to cut public spending, the sports board has been replaced by an entity responsible for a range of 
leisure-time activities, while civil society volunteers are expected to be more involved in organizing sport and physical activities and in maintenance work. Reforms in financial practices mean that annual support for sport clubs has declined while funding has become more competitive and project-based (Itkonen \& Salmikangas 2015: 552). More public sector work is outsourced, particularly to the private sector. The new situation has been highlighted by revisions in 2015 to the Sport Act, which centred on working conditions, fair competition practices, the increased supply of sports services between different sectors, and advancing business opportunities. Municipalities are now required to look to the private or third sectors, to tender for better or cheaper services such as maintaining skiing tracks or delivering swimming lessons (Hyytinen \& Kivistö-Rahnasto 2015: 16). Overall, there is a clear risk that the growing influence of market processes will undermine the basic rationale of the Finnish and wider Nordic models of sport and physical activity 'for all'. These processes may sharply divide between those who can and those who cannot afford to do sport and exercise, with clear potential impacts for social and health services.

While neoliberalism appears as an external threat to the Nordic model, we might recall that Nordic societies are not passive in this process. On one hand, Nordic societies are able to engage selectively with global policy models - not just neoliberalism - by rejecting, adapting or transforming these models (in other words, 'glocalizing' them), according to national needs, interests and values (Robertson 1995). Thus, we find that Nordic societies retain a strong public sector that coexists with the growing influence of the private sphere within sport.

On the other hand, we should also note that globalization is a two-way street. In other words, the Nordic region is well equipped to transmit its own policy models across the world as well as to receive neoliberalism and other policy models (cf. Alestalo et al. 2008). The Nordic model has aspects that are extremely attractive to many other regions. The participatory model of Nordic sport - enshrined in the 'sport for all' ethos - is of real interest to both developed and developing nations that are seeking to tackle their long-term health 'crises' by making their 
sedentary citizens much more physically active. In sport, the Nordic emphasis on democracy, transparency, equality, and inclusion would provide a strong basis for reforming the governance of sport. The social democratic thrust of the Nordic model is also strongly internationalist within the civil sphere, in promoting development, peace, the environment and social tolerance across the world. In sport, this Nordic internationalism is directly manifested in the 'sport for development and peace' sector, to which we now turn.

\section{Part 4: The Nordic Region, the World, and Sport for Development and Peace}

One important way in which the Nordic region may seek to develop and to export its models of civil society is by operating within the realm of 'global civil society'. Global civil society refers mainly to the social dimensions of globalization, particularly the forms of social development and peace-building that are to be pursued across low- and middle-income countries (LMICs). As Kaldor (2003) indicates, global civil society is a competitive field that is contested by different stakeholders in the development sector, particularly at organizational level. Thus, different international governmental bodies, nation-states, corporations, development and other nongovernmental organizations (NGOs), community-based organizations, social movements, campaign groups and others all hold their own visions and policy agendas with respect to what global civil society should look like, what its development priorities should be, and who should be involved in setting these agendas and in implementing these visions.

The dominant model of global civil society tends to advocate neoliberal, liberaldemocratic development policies, which are favoured particularly by North American and West European nations, global corporations, and much of the United Nations system including the World Bank and International Monetary Fund. In following this broad neo-liberal model, states tend to pursue a free-market, low-tax, low-welfare economy that is open (or exposed) to global markets. In LMICs in particular, neoliberal policies can leave huge gaps in the delivery of welfare and social 
services; in order to fill some of these gaps, international NGOs are often called in, with their funding agencies (such as the World Bank, or Western governments) largely determining what work 'needs to be done'. In extreme cases, this work involves humanitarian relief missions in the most demanding circumstances; much more commonly, such work includes development programmes in education, health, poverty reduction, peace-building and community cohesion. Much of this activity has been directed towards achieving the United Nations' development goals, most recently the Sustainable Development Goals which run to 2030 (UN 2015).

The Nordic region’s very strong contribution to global development has three significant themes. First, the Nordic nations offer at least partial alternatives to neoliberal approaches, by acting as 'norm entrepreneurs' for the promotion of welfare society principles such as participatory democracy, political transparency, human rights, gender and other social equality, and social justice in LMICs. Second, in broad terms, development and aid are ideal policy spaces for small, social democratic nation-states to exercise influence internationally, and to showcase their 'soft power' capabilities through forms of humanitarian diplomacy (Tvedt 1998). Third, as Gjølberg (2010: 219) indicates, the ‘solidaristic internationalism’ of Nordic societies is confirmed financially and organizationally, by going beyond the UN's target of $0.7 \%$ of national gross domestic product (GDP) to be contributed to development programmes, while their development agencies and foreign embassies are highly prominent in social projects across the global South and in post-conflict regions.

Since the early 2000s, the 'sport for development and peace' (SDP) sector has grown rapidly to become a significant component of this global civil society, and has featured substantial involvement by Nordic nations. SDP programmes and campaigns use sport as an intervention tool in order to promote diverse social development and peace-building benefits. SDP activity also tends to benefit substantially from 'development of sport' policies; that is, from developing the sport infrastructure per se, such as in training coaches and building facilities. 
The Nordic nations have been long involved in international sport development, and this activity has four main aspects. First, the classic model has involved Nordic nations providing support, particularly finances and training, for SDP initiatives that are run by different NGOs. In Zambia, for example, Kicking Aids Out was started through support from the Norwegian Agency for Development Cooperation (NORAD) and the Norwegian Olympic and Paralympic Committee and Confederation of Sports (NIF). Beginning in the Balkans, and supported by UEFA and many governmental bodies, the Danish NGO 'Open Fun Football Schools’ has been running crosscommunity summer activities for children of different national or ethnic backgrounds since the late 1990s (Gasser \& Levinson 2004). Elsewhere, in the post-conflict Balkan countries, peace-building SDP activities are supported by national embassies, development agencies and NGOs from Finland, Norway, Sweden and Denmark.

Second, blended activities involve both development of sport and SDP initiatives. For example, the Norwegian Olympic and Paralympic Committee and Confederation of Sports (NIF) began sport development work in Africa in Tanzania, Zimbabwe and Zambia, working with national sport organizations to develop sport infrastructure, and supporting the development of SDP activities. At different junctures this work has also included close collaboration with the Norwegian agencies NORAD and NIF, alongside the Strømme Foundation (Banda 2010: 326; Straume 2013). A further example is provided by LiiKe, a Finnish NGO in the field of sport development, which has worked together with its counterpart, Sports Development Aid, in Tanzania, to train teachers and peer coaches to deliver quality sport education, to lead sport clubs, and to hold health education seminars. This organization has built and maintained hundreds of sports fields for state schools and provided sports and educational equipment such as balls, nets, goalposts, racquets and books.

Third, Nordic nations run some large-scale mass sport events which ensure significant involvement by LMICs. For example, the annual Norway Cup tournament, reputedly one of the world's largest football tournaments, features around 40,000 players and over 1,400 teams drawn 
from around 50 nations. The event supports the participation of around 50 teams from the global South, particularly African sides (Hognestad \& Sauvik 2011).

Fourth, more explicitly, the influence of left-wing parties is evidenced in how some Nordic nations pursue progressive political change within sport. For example, the Danish NGO, 'Play the Game', is committed to 'the ethical foundation of sport' and promotes 'democracy, transparency and freedom of expression in sport'. ${ }^{5}$ Play the Game has indirect governmental ties, in being 'run by the Danish Institute for Sports Studies, an independent institution set up by the Danish Ministry of Culture'. ${ }^{6}$ It has been particularly critical of corrupt governance, restrictions on investigative media, and human rights abuses in sport. Earlier research also found that Nordic states were committed to promoting social democratic causes through SDP. For example, the Finnish embassy in Kosovo reported that its support for programmes and initiatives was centred on democracy, transparency, rule of law, gender equality, and human rights (Giulianotti et al. 2016).

Norway has played a particularly important and long-standing role in the emergence and establishment of the international sport development movement. NIF and the Norwegian Agency for Development Cooperation (NORAD) have backed international sport development since at least the mid-1980s, particularly in Africa, and this work has extended to encompass wider activities now associated with the SDP sector. Norway was also central to the creation of the Olympic-based SDP movement. The local organizing committee for the 1994 Lillehammer Winter Olympics established 'Olympic Aid’ which, in partnership with various sport celebrities and national and international NGOs such as the Norwegian Refugee Council and the Red Cross, generated revenues to support humanitarian work in conflict regions. Olympic Aid continued to operate after the Games, and was subsequently rebranded in 2003 as the global NGO 'Right to Play’, based in Canada and under the leadership of the Norwegian former Olympic speed-skating gold-medallist Johann Olav Koss (Coalter 2013: 26).

\footnotetext{
${ }^{5}$ See http://www.playthegame.org/.

${ }^{6}$ See http://www.playthegame.org/about/.
} 
Overall, the Nordic nations have long had a very extensive role in shaping the SDP sector. This involvement has had a dual purpose. First, SDP is a 'natural' site of activity for the democratic and humanitarian values of Nordic nations to be promoted and implemented across a transnational terrain. Second, SDP also enables these small, rich nations to exercise political and diplomatic influence and 'soft power' within the international sport system and wider global civil society.

\section{Concluding Comments}

Sport and physical activity cultures in Nordic societies have been strongly embedded within much welfare and wider social policy within the region. These processes are reflected in how women have been active figures in Nordic sport cultures, for example in leading some areas of gymnastics. The strong and over century-long civic society of physical activity and sport in Nordic countries has made it possible to have a dialogue with politicians and representatives of public administration. Sport decision-makers have often acted as political decision-makers and undertaken effective lobbying for sport. This kind of dual role has strengthened the position of sport as a significant sector of society. In addition, the public sector has been ready to give resources and to support the construction of facilities for sport and physical activity.

The strong civil society in Nordic countries has functioned as an intermediary network between citizens and the state's civil service. This has helped officials and employees in sport and physical activity associations to be more open to hearing the views and requests of the public on sport issues. In turn, the public have come to influence political decision-makers, with the result that sport and physical activity can be more effectively promoted in the society.

Civil society organizations and actors have largely been responsible for the organization of sport and physical activity in much of the Nordic region. Thus, the public sector has understood the significance of voluntary work for these civil actors - moreover, this work cannot be 
provided by any other actors. The position of physical activity has been strengthened by the fact that physical activity is seen as a promoter of wellbeing and health. The inactivity of citizens has been tackled by projects which have been implemented by civil actors, the public sector and increasingly private companies. Sport clubs, as voluntary organizational actors, are responsible especially for the activities of young people. In addition, equality issues are dealt with through adapted forms of physical activity, for example which facilitate the participation of people with disabilities.

The close connection of the civil society of sport and physical activity to the state and political decision-making has had larger impacts. Decision-makers have sought directly to promote the physical activity of citizens and to pursue other positive social goals. Sport and physical activity have been seen as important factors in promoting equality across different genders, population groups, and at the international level. All in all, the strong Nordic civil society has strengthened the position of sport and physical activity across the wider society. At the same time, the dominant Nordic view continues to be that society has benefitted, and will continue to benefit, from the strong role of sport within and through civil societies. 


\section{References}

Ahlqvist, T. and S. Moisio. 2014. "Neoliberalisation in a Nordic State: From Cartel Polity towards a Corporate Polity in Finland.” New Political Economy 19 (1): 21-55.

Alapuro, R. and H. Stenius. 1989. "Kansanliikkeet loivat kansakunnan [Popular movement created the nation]. In Kansa liikkeessä [The nation in motion], edited by R. Alapuro, L. Liikanen, K. Smeds \& H. Stenius, 5-52, Vaasa: Kirjayhtymä.

Alestalo, M, S.E.O. Hort and S. Kuhnle. 2009. The Nordic Model: Conditions, Origins, Outcomes, Lessons. Working Papers No.41, Berlin: Hertie School of Governance.

Andersen, T.M, B. Holmström, S. Honkapohja, S. Korkman, H.T. Söderström and J. Vartiainen. 2007. The Nordic Model: Embracing Globalization and Sharing Risks. Yliopistopaino, Helsinki: Taloustieto Oy.

Antikainen, A. and R. Rinne. 2012. ”Ylikansalliset paineet, pohjoismainen malli ja suomalainen koulutus. [Supranational pressures, the Nordic model and Finnish education]”. In Tiedon ja osaamisen Suomi. Kasvatus ja koulutus Suomessa 1960-luvlta 2000-luvulle. [Knowledge and expertise in Finland. Education and training in Finland from the 1960s to 2000s], edited by P. Kettunen and H. Simola, 441-479, Kariston Kirjapaino Oy: Hämeenlinna.

Ball, S. 2012. “Our Days are Numbered! Neoliberialism, Metagovernance and Performativity”. In Koulutuksen yhteiskunnallinen ymmärräys. [Social Perspectives on Education], edited by J.

Kivirauma, A. Jauhiainen, P. Sepppänen \& T. Kaunisto, 45-61, Suomen kasvatustieteellinen seura, Kasvatusalan tutkimuksia 59. Jyväskylän yliopistopaino. 
Banda, D. 2011. "Sport in Action: Young People, Sex Education and HIV/AIDS in Zambia”. In Routledge Handbook of Sports Development, edited by B. Houlihan and M. Green, 323-336, London: Routledge.

Bergsgard, N.A. and J. Norberg. 2010. “Sport Policy and Politics - the Scandinavian Way”. Sport in Society 13 (14): 567-582.

Carlsson, B. and J.P. Backman (2015) 'The Blend of Normative Uncertainty and Commercial Immaturity in Swedish Ice Hockey’, Sport in Society, 18(3): 290-312.

Coalter, F. 2013. Sport for Development: What Game Are We Playing? London: Routledge.

Eliasoph, N. 2013. The Politics of Volunteering. Cambridge: Polity.

Esping-Andersen, G. 1989. The Three Worlds of Welfare Capitalism. Cambridge: Polity.

Fahlén, J. (2006) Structures Beyond the Frameworks of the Rink: On Organization in Swedish Ice Hockey, unpublished PhD thesis, Department of Education, Umeå University.

Gasser P.K. and A. Levinsen 2004. "Breaking Post-War Ice: Open Fun Football Schools in Bosnia and Herzegovina.” Sport in Society 7: 457-472.

Giulianotti, R., H. Collison, S. Darnell and P.D. Howe 2016. “Contested States and the Politics of Sport: The Case of Kosovo - Division, Development and Recognition.” International Journal of Sport Policy and Politics, available at: http://dx.doi.org/10.1080/19406940.2016.1217251.

Gjølberg, M. 2010. "Varieties of Corporate Social Responsibility (CSR): CSR Meets the Nordic Model”. Regulation and Governance 4: 203-229.

Green, M. and S. Collins. 2008. "Policy, Politics and Path Dependency: Sport Development in Australia and Finland.” Sport Management Review 11: 225-251. 
Hentilä, S. 1982. Suomen työläisurheilun historia I. [The history of workers’ sport I] Karisto: Hämeenlinna.

Hognestad, H. 2015. “'Rimi Bowl’ and the Quest for Authenticity: Fan Autonomy and Commodification in Norwegian Football. Journal of Sport and Social Issues 39 (2): 139-154.

Hognestad, H. and L.B. Sauvik 2011. Mutuality or Patronage? A Review of the Norway Cup as an Arena for Development Cooperation. Bø: Telemark University College, Norway.

Hyytinen, T. and J. Kivistö-Rahnasto 2015. Liikuntapalvelujen ulkoistaminen ja palveluiden turvallisuus. Nykytilanne ja kuntien kokemukset. [The outsourcing of sports services and safety services. The current situation and the experiences of municipalities]. Opetus- ja kulttuuriministeriön julkaisuja 9.

Ilmanen, K. 1995. ”Kunnallinen liikuntatoimi 1919-1994. [Municipal sport 1919-1994]”. In Liikuntaa kaikelle kansalle. Valtion läänien ja kuntien liikuntahallinto 1919-1994. [Sport for all people. Sport administration at state, province and municipal levels], edited by J. Juppi, H. Klemola, K. Ilmanen \& J. Aunesluoma, 213-339, Liikuntatieteellisen Seuran julkaisu, 142. Ilmanen, K. 2015. ’Liikuntapalvelujen muutos 1800-luvun lopulta 2000-luvulle.” [Changes in sport services from the end of 1800s to the 2000s]. In Liikunta yhteiskunnallisena ilmiönä. [Physical activity as social phenomenon], edited by H. Itkonen and A. Laine, University of Jyväskylä, Department of Sport Science.

Itkonen, H. 1996. Kenttien kutsu. Tutkimus liikuntakulttuurin muutoksesta. [The call of the fields. Research on change in sport culture].Tampere: Gaudeamus.

Itkonen, H. 1999. Conditioning Tolerance? A Study of Tolerance in the Culture of Sport. University of Joensuu. Publications of Karelian Institute. No.127. Joensuu. 
Itkonen, H. 2000. Kansalaistoiminnan suuri linja [The great development line of civic activities]. In Liikunnan kansalaistoiminta - muutokset, merkitykset ja reunaehdot [Civic activities of sport and physical activities - changes, meanings and preconditions], edited by H. Itkonen, I. Heikkala, J. K. Ilmanen and P. Koski, 11-25, Liikuntatieteellisen Seuran julkaisu, 152.

Itkonen, H. 2002. ”Sport and Civil Society. Sociological Perspectives.” University of Joensuu. Publications of Karelian Institute. No. 134. Joensuu.

Itkonen, H. 2011. “Changing Roles and Practices of Sport Actors in Local Context,” Portuguese Journal of Sport Sciences 11 (1): 327-330.

Itkonen, H. 2015. ”Kansalaistoimintojen kaudet ja muuttuvat käytännöt. [The ages of civil society and changing practices].” In Liikunta yhteiskunnallisena ilmiönä. [Sport as social phenomenon], edited by H. Itkonen and A. Laine, University of Jyväskylä. Department of Sport Sciences.

Itkonen, H. and A-K. Salmikangas. 2015. “The Changing Roles of Public, Civic and Private Sectors in Finnish Sports Culture.” Public Policy and Administration 14 (4): 545-556.

Itkonen, H. and M. Simula. 2008. “Kylä liikkumisen tilana - Sivakan lämpimät kiireet [The village as a space for physical activity - the hurries of Sivakka]”. In Kylän paikka: uusia tulkintoja Sivakasta ja Rasimäestä. [The place of the village: new interpretations of Sivakka and Rasinmäki], edited by S. Knuuttila, P. Rannikko, J. Oksa, T. Hämynen, H. Itkonen, H. Kilpeläinen, M. Simula, S. Vakimo, \& M. Väisänen, 173-206, Helsinki: Suomalaisen Kirjallisuuden Seuran toimituksia [Finnish Literary Society] 1167, 2008.

Jalava, M. 2012. The University in the Making of the Welfare State: The 1970s Degree Reform in Finland. Frankfurt: Peter Lang. 
Junghagen, S. (2016) 'Tensions in Stakeholder Relations for a Swedish Football Club: A Case Study', Soccer \& Society, forthcoming.

Kaldor, M. 2003. Global Civil Society: An Answer to War. Cambridge: Polity.

Kettunen, P. 2006. ”Pohjoismainen hyvinvointivaltio yhteiskunnan kehittämisen historiana. [Nordic welfare state developing societies].” In Historiallinen käänne. Johdatus pitkän aikavälin historian tutkimukseen. [The historic turnaround. Introduction to the study of long-term history], edited by J. Saari, 217-256, Helsinki: Gaudeamus.

Kidd, B. and P. Donnelly. 2000. “Human Rights in Sports.” International Review for the Sociology of Sport 35 (2): 131-148.

Kokkonen, J. 2015. Suomalainen liikuntakulttuuri - juuret, nykyisyys ja muutossuunnat [Finnish sport culture - past, present and directions of change]. Helsinki: Suomen Urheilumuseosäätiön tutkimuksia 3.

Kuntoliikunnan suunnittelu 1970. [Planning of sport for all]. Niemen toimikunnan mietintö. Komiteamietintö 1970: B 59.

Laine, A. 2015. ’Liikunta-alan yrityskenttä [The private sector of sport and physical activity]”. In Liikunta yhteiskunnallisena ilmiönä. [Physical activity as social phenomenon], edited by H. Itkonen and A. Laine, University of Jyväskylä, Department of Sport Science.

Laine, L. 1984. Vapaaehtoisten järjestöjen kehitys ruumiinkulttuurin alueella Suomessa v. 18561917. [Development of voluntary organizations in the area of body culture in Finland 1856-1917]. Liikuntatieteellisen Seuran julkaisu No 93A/B. Lappeenranta.

Marginson, S. 2015. ”The Landscape of Higher Education Research 1965-2015. Equality of Opportunity: The first fifty years.” SRHE 50th Anniversary Collogium, 2 June 2015: Valuing 
Research into Higher Education. Available at:

https://www.srhe.ac.uk/downloads/SimonMarginsonKeynote.pdf.

Ministry of Culture and Education, Finland. 2015. Act on the promotion of sports and physical activity, 390/2015, available at: http://www.finlex.fi/en/laki/kaannokset/2015/en20150390.pdf.

Nygren, H. 1989. 1800-luvulla Suomessa perustetut urheiluseurat. [Sports clubs founded in Finland in the 1800s]. Helsinki: Suomen urheilumuseosäätiö.

Pfister, G. and M.K. Sisjord (eds) 2013. Gender and Sport: Changes and Challenges, Münster: Waxmann.

Robertson, R. 1995. “Glocalization: Time-Space and Homogeneity-Heterogeneity.” In Global Modernities, edited by M. Featherstone, S. Lash and R. Robertson, 35-55, London: Sage.

Scott, C.G. .2015. African Footballers in Sweden. Basingstoke: Palgrave

Siisiäinen, M. 1991. ”Järjestöverkon muotoutuminen Suomessa [The formation of the organizational network in Finland].” In Suomen Kartasto 321 [Finnish Atlas 321], edited by R. Sairinen, 2-6, Helsinki: Karttakeskus [State Map Centre].

Skille, E.A. 2011. "Sport for All in Scandinavia: Sport Policy and Participation in Norway, Sweden and Denmark.” International Journal of Sport Policy and Politics 3 (3): 327-339.

Straume, S. 2013. Sport for All in New Settings: A Study of the Norwegian Confederation of Sports' Sport for All Projects in Tanzania in the 1980s and Zimbabwe in the 1990s. Oslo: Norwegian School of Sport Sciences.

The Economist. 2013. “The Nordic Countries: The Next Supermodel.” 2 February 2013. 
Trägårdh, L. 2007. “The Civil Society Debate in Sweden: The Welfare State Challenged.” In State and Civil Society in Northern Europe: The Swedish Case Reconsidered, edited by L. Trägårdh, 936, Oxford: Berghahn.

Tvedt, T. 1998. Angels of Mercy or Development Diplomats? Oxford: James Currey.

United Nations (UN) 2010. Contribution of Sport to the Millennium Development Goals. New York: United Nations.

United Nations (UN) 2015. Transforming our World: The 2030 Agenda for Sustainable Development. New York: United Nations.

United Nations (UN). 2003. Sport for Development and Peace: Towards Achieving the Millennium Development Goals. New York: United Nations.

Vasara, E. 1997. Valkoisen Suomen urheilevat soturit. Suojeluskuntajärjestön urheilu- ja kasvatustoiminta vuosina 1918-1939 [Sporting Warriors of White Finland: Sports and Educational Activities for the White Guard, 1918-1939]. Suomen Historiallinen Seura. Bibliotheca Historica 23.

Weber, M. 1972; original 1925. Wirtschaft und Gesellschaft. Grundriss der verstehenden Soziologie. Tübingen: Mohr.

Wollebæk, D. and P. Selle 2008. “A Social Democratic Model of Civil Society?” In Changing Images of Civil Society, edited by B. Jobert and B. Kohler-Koch, 47-69, London: Routledge. 